\title{
Pengurangan Subsidi BBM dan Polusi Udara Melalui KEBIJAKAN PROGRAM KONVERSI DARI BBM KE BBG UNTUK KendaraAn di Propinsi JaWa Barat
}

\author{
Vita Susanti, Agus Hartanto, Ridwan A.S., Hendri M.S., Estiko R., A. Hapid \\ Pusat Penelitian Tenaga Listrik dan Mekatronik - LIPI \\ Komp. LIPI Bandung, Jl Sangkuriang, Gd 20, Lt 2, Bandung, \\ Jawa Barat 40135, Indonesia \\ vitasusanti@gmail.com, ahartantots@yahoo.com,ridwanarief_rais@yahoo.com, \\ hendri_maja@yahoo.co.id, estiko@hotmail.com, abdul.hapid@lipi.go.id
}

Diterima: 26 Oktober 2010; Direvisi: 29 November 2010; Disetujui: 10 Desember 2010; Terbit online: 24 Desember 2010.

\begin{abstract}
Abstrak
Populasi kendaraan di Indonesia yang berbahan bakar minyak (BBM) setiap tahunnya semakin meningkat sedangkan cadangan minyak sendiri semakin menipis dan harus impor. Hal ini menyebabkan subsidi BBM dan polusi udara juga akan meningkat. Untuk mengatasi hal tersebut diperlukan bahan bakar alternatif yang ramah lingkungan sebagai pengganti BBM untuk kendaraan. Salah satu bahan bakar alternatif tersebut adalah bahan bakar gas (BBG). Dilihat dari jumlah kendaraan dan infrastruktur jaringan pipa gas, daerah Jawa Barat bagian utara sangat berpotensi untuk dijadikan tempat dilaksanakannya program konversi BBM ke BBG pada kendaraan. Populasi kendaraan di wilayah tersebut meliputi Depok, Cibinong, Bogor, Bekasi, Cikarang, Karawang, Purwakarta, Cirebon, dan Bandung yang berjumlah 878.505 unit. Dari data tersebut dapat disimulasikan seberapa besar potensi keuntungan yang akan didapat dengan mengkonversi $10 \%$ dari jumlah kendaraan pada tahun pertama dan kenaikan pertahunnya sebesar 5\%. Dengan dana investasi sebesar 3,16 triliyun rupiah maka akan didapat keuntungan sebesar 14,9 triliun rupiah berupa penghematan subsidi dan penghematan bahan bakar. Selain itu, pengurangan emisi yang dikonversi ke CDM (clean development mechanism) dapat menjadi pendapatan daerah dengan total CDM yang dihasilkan selama 5 tahun sebesar US\$ 772.385. Dari hasil kajian ini dapat disimpulkan bahwa manfaat konversi BBM ke BBG pada kendaraan sangatlah besar.
\end{abstract}

Kata Kunci : bahan bakar gas, kebijakan, konversi, polusi udara, subsidi.

\begin{abstract}
The number of vehicle that use oil (BBM) is increasing every year in Indonesia while national oil reserve become smaller, so that the oil should be imported. The impact of using oil are increasing subsidy and air pollution. Thus, it is now becoming important to replace oil with another enviromentally friendly energy, one of them is gas $(B B G)$. Based on the number of vehicle and infrastructure in gas pipeline, part of northern West Java potentially can be chosen for the implementation of conversion program to gas (BBG). The number of vehicle in potential regions such as Depok, Cibinong, Bogor, Bekasi, Cikarang, Karawang, Purwakarta, Cirebon, and Bandung are around 875,505 units. From these data, we simulated the potential profit to be gained each year by converting 10\% for the first year and increasing it to 5\% for every year. By investing 3.16 trillion for conversion, 14.9 trillion can be achieved in the form of fuel subsidy savings. In addition, emission reduction converted to a CDM (clean development mechanism) can become local revenues. Total CDM generated during 5 years predicted is of U.S $\$ 772,385$. From this study, it can be concluded that converting oil (BBM) to gas (BBG) is highly beneficial.
\end{abstract}

Keyword: natural gas, policy, conversion, air pollution, subsidy.

\section{Pendahuluan}

\section{A. Latar Belakang}

Jumlah kendaraan di Indonesia dari tahun ke tahun makin meningkat. Untuk Propinsi Jawa Barat saja jumlah kendaraan per 30 Juni 2010 sebanyak 8,9 juta (kendaraan roda 2 dan roda 4) dan tentu saja emisi yang dihasilkan dari asap kendaraan bermotor tersebut sangatlah besar. Di sisi lain, Indonesia saat ini bukan lagi negara eksportir minyak. Indonesia sejak tahun 2005 mulai mengimpor minyak untuk memenuhi kebutuhan minyak di dalam negeri sehingga pemerintah harus mengeluarkan dana untuk mensubsidi BBM tersebut. Pada tahun 2010 ini pemerintah harus mengalokasikan dana untuk subsidi bahan bakar minyak (BBM) sebesar Rp 57,4 triliyun, sehingga semakin banyak populasi kendaraan di Indonesia maka semakin besar juga subsidi yang harus dialokasikan oleh pemerintah. 
Selain masalah sumber energi dan subsidi, muncul juga permasalahan pencemaran lingkungan dari hasil pembakaran BBM pada kendaraan, seperti gas $\mathrm{CO}_{2}$ (carbon dioksida), PM10 (particulate matter $\leq 10 \mu$ ), $\mathrm{Pb}$ (timbal), dan lain-lain. Presiden Republik Indonesia, Bapak Susilo Bambang Yudhoyono pada pertemuan negara-negara berkembang (Group of 77) berjanji akan mengurangi emisi sebesar $26 \%$ pada tahun 2020. Langkah yang diambil oleh Kementrian Lingkungan Hidup dan jajarannya untuk mengurangi emisi tersebut adalah dengan penanaman pohon, pengujian emisi kendaraan bermotor dan pengolahan sampah. Namun demikian sebenarnya sumber emisi terbesar berasal dari asap kendaraan bermotor.

Data dari Departemen Perhubungan menunjukkan bahwa polusi $\mathrm{CO}_{2}$ yang dihasilkan pada tahun 2003 dari sistem transportasi adalah sebesar 168 juta ton. Sejalan dengan bertambahnya kendaraan, maka pada tahun 2007 pencemaran $\mathrm{CO}_{2}$ juga bertambah menjadi sekitar 324 juta ton [1].

Perkembangan pencemaran lingkungan tersebut memberikan dampak yang tidak baik bagi kesehatan penduduk. Contohnya seperti yang terdapat di Kota Batam dimana dampak kesehatan yang ditimbulkan oleh pencemaran polutan $\mathrm{PM} 10$ dan $\mathrm{Pb}$ adalah berupa kasus penderita mortalitas prematur, penyakit saluran pernafasan dengan rawat inap, kasus gawat darurat, terhambatnya hari aktivitas, bronkhitis pada anak-anak, kasus baru asma kronis, serangan asma, berkurangnya hari aktivitas karena gejala penyakit, kasus kardiovaskular, kehilangan IQ per anak, hipertensi, serangan jantung tidak fatal, dan mortalitas. Biaya kesehatan total yang meliputi ongkos pengobatan yang harus dikeluarkan akibat polutan PM10 dan $\mathrm{Pb}$ serta production loss yang ditimbulkan untuk seluruh Kota Batam mencapai nilai Rp 630,733 milyar ( $8 \%$ dari PDRB Kota Batam) [1]. Data lainya yaitu dari hasil penelitian Institut Teknologi Bandung yang dilakukan pada tahun 2005 bahwa $66 \%$ anak sekolah yang sekolahnya berada di pusat kota Bandung, darahnya mengandung polutan yang melebihi ambang batas [2].

Pembahasan tentang dampak dari polusi kendaraan bermotor tidak lepas dari populasi kendaraan bermotor tersebut yang terus meningkat dari tahun ke tahun. Berdasarkan data dari Dinas Pendapatan Daerah Propinsi Jawa Barat, jumlah kendaraan roda 4 (kendaraan umum, bukan umum dan dinas) di kabupaten/kota yang potensinya besar seperti Depok, Cibinong, Bogor, Bekasi, Cikarang,
Karawang, Purwakarta, Cirebon dan Bandung adalah sebanyak 878.505 unit kendaraan. Dari populasi tersebut dapat dihitung emisi $\mathrm{CO}_{2}$ yang dihasilkan dengan asumsi jarak tempuh setiap kendaraan adalah $100 \mathrm{~km} /$ hari, jumlah hari dalam 1 tahun adalah 350 hari, dengan emisi $\mathrm{CO}_{2}$ sebesar $0,1667 \mathrm{~kg} / \mathrm{km}$ [3], maka besarnya emisi $\mathrm{CO}_{2}$ yang dihasilkan selama 1 tahun adalah 5,16 juta ton.

Dari latar belakang tersebut di atas kiranya dibutuhkan bahan bakar yang ramah lingkungan sebagai pengganti bahan bakar minyak pada kendaraan. Salah satu bahan bakar yang ramah lingkungan tersebut adalah bahan bakar gas (BBG).

\section{B. Tujuan}

Makalah ini bertujuan untuk memberikan gambaran dan informasi mengenai keuntungan yang akan diperoleh bila dilakukan program konversi BBM ke BBG pada kendaraan di Propinsi Jawa Barat.

\section{Metodologi}

Metodologi yang digunakan pada makalah ini adalah:

1. Survey data sekunder dari internet.

Data-data yang didapat dari internet berupa standar-standar kits konverter yang sudah ada, teknologi kit konverter, perkembangan Natural Gas Vehicle (NGV) di luar negeri, dan peraturanperaturan yang mendukung konversi dari BBM ke BBG untuk kendaraan.

2. Beraudiensi dengan instansi terkait.

Melakukan audiensi dengan Dinas Perhubungan di Jawa Barat, Badan Pengelolaan Lingkungan Hidup Daerah (BPLHD) Jawa Barat, Dinas Perindustrian dan Energi DKI Jakarta, Perusahaan Gas Negara (PGN), dan lain lain. Tujuan dari audiensi ini adalah untuk mengetahui sudah sejauh mana pelaksanaan konversi dari BBM ke BBG untuk transportasi, kendala-kendala yang dihadapi, kebijakan dan peraturan apasaja yang dikeluarkan oleh instansi tersebut.

3. Analisis data.

Menganalisis data-data tentang kebijakan yang sudah ada di instansi terkait tersebut dan merumuskan kebijakan sementara.

Dari analisis data tersebut kemudian dihitung mengenai lokasi-lokasi di wilayah Jawa Barat yang potensial untuk dilaksanakannya program konversi dari BBM ke BBG. Lokasi yang dipilih adalah adalah bagian utara Jawa Barat karena, secara geografis, wilayah tersebut merupakan 
pendukung Ibu Kota Negara dan telah memiliki jaringan pipa gas serta populasi kendaraannya yang tinggi.

\section{KEBIJAKAN KONVERSI DARI BBM KE BBG}

Pembuatan kebijakan konversi dilihat dari perkembangan yang telah terjadi dan manfaat yang akan diperoleh dengan program konversi ini.

\section{A. Perkembangan Konversi dari BBM ke BBG}

Dari data yang didapat, Departemen Perhubungan sudah mengkaji mengenai konversi dari BBM ke BBG pada kendaraan sejak tahun 1980 dan pada tahun 1988 di Jakarta sudah mulai dilakukan program percontohan untuk taksi "Blue Bird" dengan mengkonversi 500 unit armadanya menggunakan BBG sebagai pengganti BBM. Selain taksi "Blue Bird", pada tahun 1990 PPD (Perusahaan Pengangkutan Djakarta) juga memiliki 40 unit armada bus menggunakan BBG tipe full dedicated dan 50 unit dengan sistem bifuel. Selanjutnya pada tahun 1997 pemerintah meluncurkan program "Langit Biru" untuk mendongkrak jumlah kendaraan yang menggunakan bahan bakar gas.

Konversi dari BBM ke BBG tidak hanya dilaksanakan di Jakarta saja, tetapi juga di kota lainnya. Pada tahun 1997-1998, di kota Bandung juga pernah dilaksanakan uji coba konversi BBM ke BBG untuk transportasi. Pada saat itu uji coba BBG diterapkan pada angkutan kota rute "Margahayu-Ledeng" sebanyak 35 unit. Kit konverter yang digunakan berasal dari bantuan Australia. Selain mendapat bantuan dari Australia, dana APBD (Anggaran Pendapatan dan Belanja Daerah) juga digunakan untuk pengadaan kit konverter yang dipasang pada kendaraan Dinas Pemerintah. Total kendaraan angkutan kota dan mobil dinas yang menggunakan BBG sebanyak 80 unit. Pada saat itu Stasiun Pengisian Bahan Bakar Gas (SPBG) berada di jalan Katamso. Karena di Bandung tidak terdapat jaringan pipa gas maka untuk sistem supply gasnya menggunakan sistem container tank.

Dalam kurun waktu dari tahun 1988-2000 populasi kendaraan berbahan bakar gas terus meningkat, tetapi sejak tahun 2001 jumlahnya mulai menurun dan pada tahun 2004 diperkirakan hanya ada 500 unit kendaraan yang menggunakan BBG. Untuk itu sejak tahun 2007, pemerintah mulai menggalakan lagi konversi BBM ke BBG pada kendaraan dengan memberikan bantuan kit konverter untuk taksi, angkutan kota dan bajaj di Jakarta.
Di Surabaya juga mulai dikembangkan konversi BBM ke BBG untuk kendaraan, tetapi berbeda dengan kota-kota lainnya di Surabaya kit konverter yang digunakan bukan berasal dari bantuan pemerintah melainkan pihak swasta yang memberikan bantuan kredit kepada supir taksi. Hal ini dapat berjalan karena masyarakat di sana sudah mengerti manfaat yang akan didapat dengan mengkonversi kendaraannya. Sejak tahun 2007, pemerintah setiap tahun memberikan bantuan kit konverter untuk daerah-daerah yang sudah siap untuk melaksanakan program konversi BBM ke BBG pada kendaraan.

Perkembangan jumlah peralatan konversi bahan bakar gas dari tahun ke tahun dapat dilihat pada Tabel 1 berikut ini.

Tabel 1.

Jumlah peralatan konversi di Indonesia.

\begin{tabular}{cllc}
\hline No. & Tahun & Kota & $\begin{array}{c}\text { Jumlah } \\
\text { Konverter Kits }\end{array}$ \\
\hline 1. & 1988 & Jakarta & 500 \\
\hline 2. & 1990 & Jakarta & 90 \\
\hline 3. & 1997 & Bandung & 80 \\
\hline 4. & 2007 & Jakarta & 1.755 \\
\hline 5. & 2007 & Surabaya & 500 \\
\hline 6. & 2008 & Jakarta & 840 \\
\hline 7. & 2009 & Bogor & 1.001 \\
\hline 8. & 2009 & Palembang & 666 \\
\hline 9. & 2010 & Surabaya & 500 \\
\hline
\end{tabular}

\section{B. Dampak Konversi dari BBM ke BBG}

Pemakaian bahan bakar gas pada kendaraan akan berdampak positif. Beberapa dampak tersebut dijelaskan seperti berikut.

\section{1) Mengurangi pemakaian BBM}

Hal ini berarti mengurangi subsidi dan mengurangi impor minyak. Hal tersebut dapat dihitung dan diformulasikan seperti di bawah ini.

$$
\begin{aligned}
& G_{1}=\sum_{i=1}^{5} J_{n} * K_{1} * J_{2} \\
& G_{2}=\sum_{i=1}^{5} J_{n} * K_{2} * J_{2} \\
& P_{1}=G_{1} * H_{1} \\
& P_{2}=G_{2} * H_{2} \\
& P_{3}=G_{1} * H_{3} \\
& S_{1}=P_{1}-P_{2} \\
& S_{2}=P_{3}-P_{2}
\end{aligned}
$$




$$
\begin{aligned}
& I=\left(J_{n}-J_{n-1}\right) * H_{4} \\
& B=\left(S_{1}+S_{2}\right)-I
\end{aligned}
$$

Keterangan:

$\mathrm{B}$ = keuntungan

$\mathrm{G} 1$ = penggunaan BBM pertahun

$\mathrm{G} 2$ = penggunaan $\mathrm{BBG}$ pertahun

$\mathrm{H} 1$ = harga BBM

$\mathrm{H} 2$ = harga BBG

$\mathrm{H} 3$ = harga BBM non subsidi

$\mathrm{H} 4$ = harga kit konverter

I $=$ investasi

Jn = jumlah kendaraan roda 4 pada tahun ke-n

$\mathrm{J} 2=$ jumlah hari dalam 1 tahun

$\mathrm{K} 1=$ konsumsi BBM per hari

$\mathrm{K} 2$ = konsumsi BBG per hari

$\mathrm{n}=1, \ldots ., 5$

$\mathrm{P} 1=$ pengeluaran $\mathrm{BBM}$

$\mathrm{P} 2$ = pengeluaran $\mathrm{BBG}$

P3 = pengeluaran BBM non subsidi

$\mathrm{S} 1$ = penghematan bahan bakar

$\mathrm{S} 2$ = penghematan subsidi

\section{2) Mengurangi pencemaran lingkungan}

Dengan menggunakan BBG maka emisi gas buang yang dihasilkan sangat kecil. Apabila semua kendaraan yang menggunakan BBM di daerah berpotensi di Jawa Barat tersebut menghasilkan emisi 5,16 juta ton $\mathrm{CO}_{2}$, maka emisi $\mathrm{CO}_{2}$ akan berkurang sebesar 1,8 juta ton bila semua kendaraan tersebut dikonversi ke BBG. Nilai emisi $\mathrm{CO}_{2}$ di atas, dapat dihitung dan diformulasikan sebagai berikut :

$$
E m=V_{E m} * \sum_{i=1}^{5} J_{n} * J_{3} * J_{2}
$$

Keterangan :

$$
\begin{aligned}
\mathrm{Em} & =\text { emisi } \\
\mathrm{J} 3 & =\text { jarak tempuh perhari } \\
\mathrm{VEm}= & \text { variabel emisi } \mathrm{CO}_{2}, \mathrm{CO}, \mathrm{NOx}, \mathrm{HC}, \text { dan } \\
& \text { partikel yang digunakan sebagai } \\
& \text { variabel pengurang emisi. }
\end{aligned}
$$

Dari perhitungan emisi bisa dikonversi ke $C D M$ yang diformulasikan sebagai berikut:

$$
C D M=\left(\frac{E m}{1000}\right) * \$ 10
$$

\section{3) Menambah peluang usaha}

Keberhasilan program ini berpotensi untuk meningkatkan peluang usaha dari industri hilir sampai ke industri hulu serta industri kit konverter itu sendiri, sehingga dapat meningkatkan lapangan kerja di berbagai sektor.
4) Bagi pengguna NGV (Natural Gas Vehicle)

Dengan menggunakan BBG maka pengguna $N G V$ dapat menghemat biaya operasional dan biaya perawatan karena harga BBG yang lebih murah dibandingkan dengan BBM.

\section{Hasil Dan Pembahasan}

Pembahasan makalah ini meliputi kendala yang dihadapi selama ini, daerah-daerah di Jawa Barat yang berpotensi dan keuntungan yang akan diperoleh.

\section{A. Kendala Program Konversi}

Hingga saat ini, pelaksanaan program konversi BBM ke BBG untuk kendaraan kurang berhasil dilihat dari jumlahnya yang kurang dari 5000 unit kendaraan berbahan bakar gas atau $N G V$. Hal ini disebabkan beberapa kendala seperti berikut.

\section{1) Pasokan Gas}

Meskipun sumber gas di Indonesia masih sangat banyak, namun pada kenyataannya quota gas untuk transportasi tidak ada. Dari data yang ada, gas yang dialokasikan untuk dalam negeri telah habis digunakan oleh industri dan pembangkit listrik. Pembangkit listrikpun masih kekurangan pasokan gas. Apalagi gas untuk transportasi yang nota bene nilai kontraknya tidak menentu. Untuk itulah diperlukan adanya jaminan quota gas untuk transportasi oleh pemerintah.

\section{2) Harga Gas}

Di Jakarta terdapat dua jenis harga gas untuk kendaraan dalam hal ini CNG (Compressed Natural Gas). Harga gas Pertamina Rp. 2.562/1sp atau liter setara premium sedangkan harga gas PGN (Perusahaan Gas Negara) adalah Rp. 3.600/1sp. Karena perbedaan harga ini, maka SPBG yang menjual gas lebih mahal kekurangan konsumen yang diakibatkan konsumennya beralih ke SPBG yang menjual gas lebih murah. Hal ini berakibat buruk karena terjadi antrian panjang dan SPBG harus beroperasi terus menerus, sehingga perawatannya terabaikan.

\section{3) $S P B G$}

SPBG yang ada selama ini sangat sedikit, dimana Jakarta memiliki jumlah kendaraan berbahan bakar gas yang tidak sebanding dengan pertumbuhan pembangunan SPBG, sehingga terjadi antrian yang cukup panjang pada saat pengisian BBG. Hal ini mengakibatkan banyak kendaraan yang tadinya menggunakan BBG jadi beralih kembali menggunakan BBM karena enggan mengantri. 


\section{4) Kit Konverter}

Kit konverter yang digunakan di Indonesia saat ini berasal dari berbagai negara, seperti Argentina, Cina dan India. Spare part atau suku cadang untuk peralatan konversi tersebut tidak tersedia di Indonesia. Jika ingin membelinya harus dalam jumlah besar dan waktu yang diperlukan untuk pengiriman juga lama. Akibatnya kendaraan yang mengalami kerusakan sangat sulit diperbaiki karena sulitnya pengadaan spare part dan pada akhirnya kendaraan tersebut kembali lagi menggunakan BBM.

\section{5) Standar}

Di Indonesia standar yang digunakan untuk peralatan konversi bahan bakar gas $(C N G)$ pada kendaraan adalah SNI 7407 : 2009 [4]. Standar ini mengacu pada beberapa standar dari luar negeri seperti AS/NZ 2739 : 2009 [5], ISO 15500 : 2001 [6], dan sebagainya. Namun butirbutir yang diacu pada SNI tidak selengkap yang ada pada standar-standar tersebut, sehingga SNI masih belum dapat dijadikan sebagai patokan. Contohnya adalah pada SNI ada bagian yang membahas mengenai instalasi, tetapi pada kenyataannya di lapangan para installer merakit peralatan konversi tersebut mengikuti panduan dari vendornya masing-masing tergantung merek peralatan konversinya. Sehingga tata letak peralatan konversi pada kendaraan satu dengan yang lainnya berbeda-beda tergantung dari vendor dan luasnya ruang yang ada pada kendaraan.

\section{6) Pengujian}

Selama ini di Indonesia tidak ada suatu lembaga atau badan yang menguji peralatan konversi, yang ada hanya pengujian pada tabung yang dilakukan oleh Departemen Tenaga Kerja. Sebelum digunakan pada kendaraan, peralatan konversi yang diimpor harus diuji terlebih dahulu. Sehingga dapat diketahui kelayakan penggunaan peralatan tersebut.

\section{7) Monitoring Evaluasi}

Sejak dicetuskannya program konversi BBM ke BBG pada kendaraan pada tahun 1988 hingga saat ini belum dilakukan monitoring dan evaluasi pada kendaraan yang menggunakan BBG, sehingga mengalami kesulitan untuk mendapatkan data populasi kendaraan.

\section{8) $C D M$}

Salah satu manfaat dari konversi BBM ke BBG pada kendaraan adalah pengurangan emisi. Pengurangan emisi yang diperoleh dapat di konversi ke CDM (clean development mechanism), sehingga 1 ton $\mathrm{CO}_{2}$ yang dikurangi dapat menghasilkan $\$ 10$. Pengurangan emisi $\mathrm{CO}_{2}$ ini dijual dalam bentuk Certified Emission Reduction (CER) ke negara-negara maju yang paling banyak menghasilkan emisi $\mathrm{CO}_{2}$.

\section{B. Daerah Potensial Program Konversi}

Pulau Jawa bagian utara dari Cilegon sampai Surabaya sudah memiliki jaringan pipa gas yang saling terhubung. Jaringan pipa gas tersebut dapat dilihat seperti pada Gambar 1 di bawah ini.

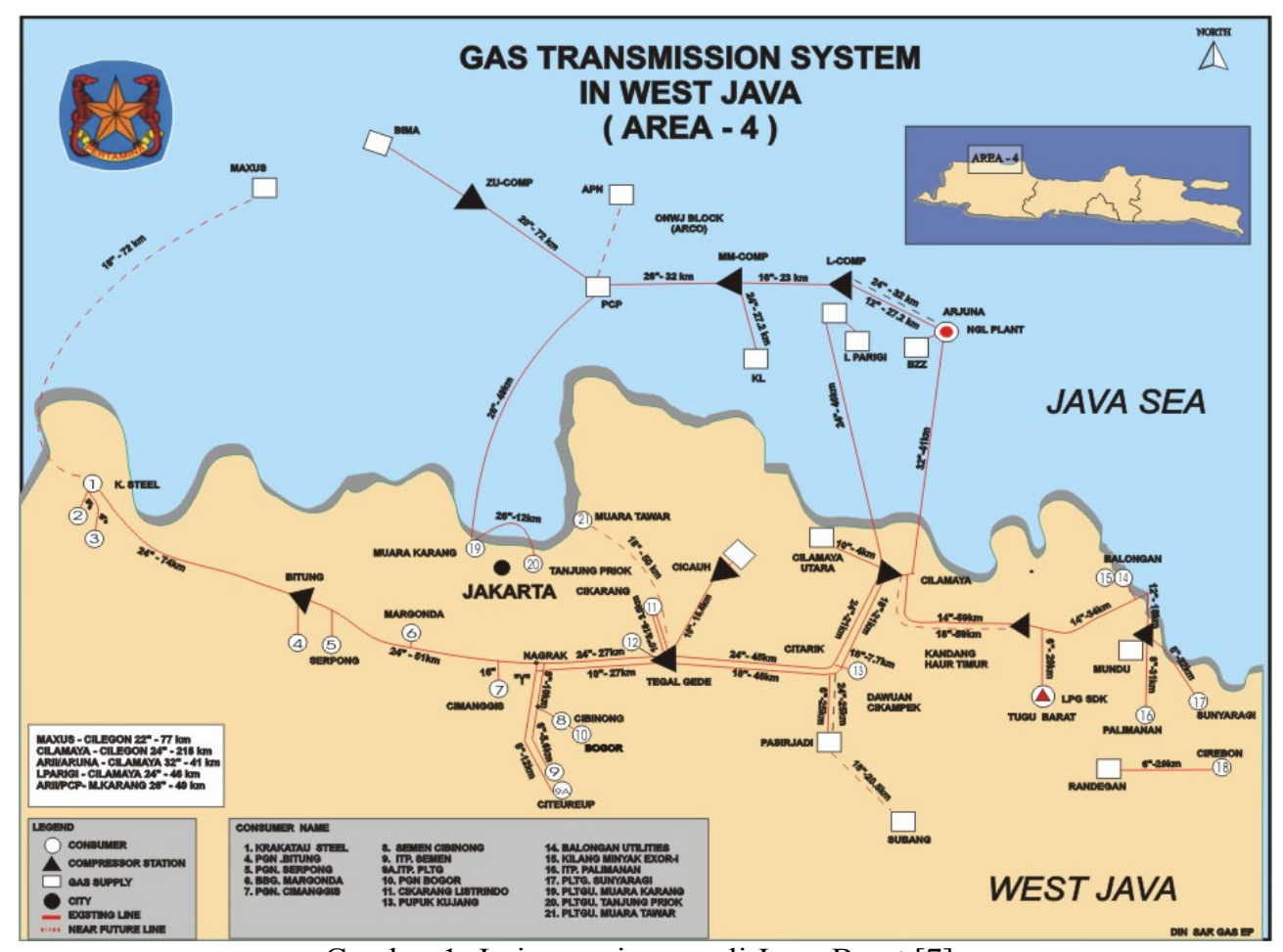

Gambar 1. Jaringan pipa gas di Jawa Barat [7]. 
Jawa Barat telah memiliki jaringan pipa gas dari Bekasi sampai Cirebon, sehingga untuk wilayah tersebut sangat berpotensi untuk dilaksanakannya program konversi BBM ke BBG ini.

Tabel 2 menunjukkan jumlah kendaraan di kabupaten/kota di Jawa Barat yang paling berpotensi untuk dilaksanakannya program ini.

Tabel 2.

Jumlah kendaraan.

\begin{tabular}{lrrr}
\hline $\begin{array}{l}\text { Kabupaten } \\
\text { dan Kota }\end{array}$ & Umum & Bukan Umum & Dinas \\
\cline { 2 - 4 } Depok & 15.594 & 55.056 & 835 \\
\hline Cibinong & 12.120 & 56.510 & 1.028 \\
\hline Bogor & 6.038 & 51.623 & 736 \\
\hline Bekasi & 16.973 & 155.637 & 1.253 \\
\hline Cikarang & 7.107 & 73.082 & 656 \\
\hline Karawang & 4.354 & 26.102 & 776 \\
\hline Purwakarta & 2.312 & 8.869 & 365 \\
\hline Cirebon & 5.144 & 27.701 & 445 \\
\hline Bandung & 12.577 & 332.196 & 3.417 \\
\hline Total & $\mathbf{8 2 . 2 1 9}$ & $\mathbf{7 8 6 . 7 7 6}$ & $\mathbf{9 . 5 1 1}$ \\
\hline
\end{tabular}

Tabel 2 adalah data kendaraan bermotor roda 4 per 30 Juni 2010 dari Dinas Pendapatan Daerah Jawa Barat di beberapa kabupaten/kota di Propinsi Jawa Barat. Tabel tersebut menunjukkan total kendaraan roda 4 yang mencakup kendaraan umum, kendaraan bukan umum, dan kendaraan dinas mencapai angka sebesar 878.505 unit kendaraan.

Dari Tabel 2 juga dapat dilihat bahwa dari segi jumlah kendaraan roda 4, kabupaten/kota Bandung, Bekasi, Depok dan Cibinong sangat berpotensi untuk melaksanakan konversi BBM ke BBG. Selain itu di kabupaten/kota tersebut juga sudah mempunyai jaringan pipa gas, kecuali Bandung.

Dari data pada Tabel 2, dapat disimulasikan perhitungan potensi untuk daerah-daerah tersebut. Dengan asumsi pada tahun pertama sebesar 10\% dari jumlah kendaraan yang dikonversi dan kemudian kenaikan konversi pertahunnya sebesar $5 \%$, sehingga pada tahun 2015 kendaraan berbahan bakar gas atau Natural Gas Vehicle $(N G V)$ akan mencapai 263.554 seperti yang terdapat pada Tabel 3 berikut ini.

Tabel 3.

Kenaikan konversi per tahun.

\begin{tabular}{lrrrrr}
\hline Kabupaten dan Kota & $\mathbf{2 0 1 1}$ & $\mathbf{2 0 1 2}$ & $\mathbf{2 0 1 3}$ & $\mathbf{2 0 1 4}$ & $\mathbf{2 0 1 5}$ \\
\hline Depok & 7.149 & 10.722 & 14.297 & 17.872 & 21.446 \\
\hline Cibinong & 6.966 & 10.449 & 13.932 & 17.415 & 20.897 \\
\hline Bogor & 5.840 & 8.759 & 11.680 & 14.600 & 17.519 \\
\hline Bekasi & 17.386 & 26.080 & 34.772 & 43.465 & 52.159 \\
\hline Cikarang & 8.085 & 12.126 & 16.168 & 20.212 & 24.254 \\
\hline Karawang & 3.123 & 4.684 & 6.246 & 7.809 & 9.370 \\
\hline Purwakarta & 1.155 & 1.732 & 2.309 & 2.886 & 3.465 \\
\hline Cirebon & 3.329 & 4.994 & 6.658 & 8.322 & 9.987 \\
\hline Bandung & 34.820 & 52.229 & 69.637 & 87.047 & 104.457 \\
\hline Total & $\mathbf{8 7 . 8 5 3}$ & $\mathbf{1 3 1 . 7 7 5}$ & $\mathbf{1 7 5 . 6 9 9}$ & $\mathbf{2 1 9 . 6 2 8}$ & $\mathbf{2 6 3 . 5 5 4}$ \\
\hline
\end{tabular}

Dari Tabel 3 di atas, dapat dilihat bahwa total kenaikan Natural Gas Vehicle selama lima tahun sebesar 30\% dari total jumlah kendaraan roda 4 pada tahun 2010.

Selanjutnya dari Tabel 3 dapat disimulasikan banyaknya Stasiun Pengisian Bahan Bakar Gas yang diperlukan di setiap kabupaten/kota. Jumlah tersebut adalah jumlah minimum yang diharapakan dapat melayani semua $N G V$ yang ada di sana. Dengan asumsi satu Stasiun Pengisian Bahan Bakar Gas dapat melayani 750 NGV, maka jumlah pembangunan Stasiun Pengisian Bahan Bakar Gas di tiap kabupaten dan kota dari tahun 2011 sampai tahun 2015 dapat dilihat pada Tabel 4 berikut ini.
Tabel 4.

Jumlah SPBG.

\begin{tabular}{lccccc}
\hline $\begin{array}{l}\text { Kabupaten } \\
\text { dan Kota }\end{array}$ & $\mathbf{2 0 1 1}$ & $\mathbf{2 0 1 2}$ & $\mathbf{2 0 1 3}$ & $\mathbf{2 0 1 4}$ & $\mathbf{2 0 1 5}$ \\
\hline Depok & 10 & 14 & 19 & 24 & 29 \\
\hline Cibinong & 9 & 14 & 19 & 23 & 28 \\
\hline Bogor & 8 & 12 & 16 & 19 & 23 \\
\hline Bekasi & 23 & 35 & 46 & 58 & 70 \\
\hline Cikarang & 11 & 15 & 22 & 27 & 32 \\
\hline Karawang & 4 & 6 & 8 & 10 & 12 \\
\hline Purwakarta & 2 & 2 & 3 & 4 & 5 \\
\hline Cirebon & 4 & 7 & 9 & 11 & 13 \\
\hline Bandung & 46 & 70 & 93 & 116 & 139 \\
\hline Total & $\mathbf{1 1 7}$ & $\mathbf{1 7 5}$ & $\mathbf{2 3 5}$ & $\mathbf{2 9 2}$ & $\mathbf{3 5 1}$ \\
\hline & & & & & \\
\hline
\end{tabular}


Tabel 4 menunjukkan bahwa daerah Bandung memerlukan 46 SPBG pada tahun pertama, dan pada tahun ke-2 diperlukan 70 SPBG. Tiap tahun kebutuhan SPBG makin meningkat sampai pada tahun ke-5 diperlukan 139 SPBG. Secara keseluruhan minimal diperlukan 351 SPBG di Jawa Barat untuk memenuhi kebutuhan suplai gas bagi Natural Gas Vehicle. Hal ini terjadi apabila konversi setiap tahunnya berjalan dengan lancar.

Kebutuhan gas selama 5 tahun di kabupaten/kota tersebut dapat disimulasikan dengan menggunakan asumsi bahwa penggunaan gas adalah 10 lsp (liter setara premium) per hari, maka besarnya kebutuhan gas di tiap kabupaten/kota dapat dilihat pada Tabel 5 di bawah ini.

Tabel 5.

Kebutuhan gas.

\begin{tabular}{lr}
\hline Kabupaten dan Kota & $\begin{array}{r}\text { Volume Gas } \\
\text { (lsp) }\end{array}$ \\
\hline Depok & 250.201 .000 \\
\hline Cibinong & 243.806 .500 \\
\hline Bogor & 204.393 .000 \\
\hline Bekasi & 608.517 .000 \\
\hline Cikarang & 282.957 .500 \\
\hline Karawang & 109.312 .000 \\
\hline Purwakarta & 40.414 .500 \\
\hline Cirebon & 116.515 .000 \\
\hline Bandung & 1.218 .665 .000 \\
\hline Total Selama 5 Tahun & $\mathbf{3 . 0 7 4 . 7 8 1 . 5 0 0}$ \\
\hline
\end{tabular}

Berdasarkan Tabel 5, pemerintah harus memenuhi kebutuhan minimal gas selama 5 tahun sebesar 3,1 milyar lsp. Perhitungan ini dengan asumsi minimal penggunaan gas tiap kendaraan per harinya adalah 10 lsp.

\section{Proyeksi Keuntungan Program Konversi}

Berdasarkan jumlah kendaraan berbahan bakar gas seperti yang terdapat pada Tabel 3, dapat disimulasikan nilai potensi keuntungan yang akan didapat dengan asumsi harga BBG Rp. 2.562 dan harga BBM bersubsidi Rp. 4.500 sedangkan harga BBM non subsidi Rp. 6.500 serta harga kit konverter Rp. 12.000.000,- per set.

Sebagai contoh kabupaten/kota yang sangat berpotensi salah satunya adalah Bandung. Untuk menghitung pengeluaran BBM, BBG, dan sebagainya terlebih dahulu dilakukan perhitungan penggunaan BBM dan BBG per tahun dengan menggunakan Persamaan (1) pada tahun pertama (2011) yaitu dengan persamaan $G_{1}=\sum_{i=1}^{5} J_{n}$ * $K_{1} * J_{2}$ maka didapat penggunaan BBM sebesar
121.870.000 liter, dan dengan menggunakan persamaan (2) $G_{2}=\sum_{i=1}^{5} J_{n} * K_{2} * J_{2}$ maka didapat besarnya penggunaan $\mathrm{BBG}$ sebesar 121.870.000 liter. Dengan menggunakan persamaan yang sama dapat dihitung penggunaan BBM dan BBG pada tahun ke-2 sampai ke-5. Total penggunaan BBM dan BBG selama 4 tahun sebesar 1.096.795.000 liter.

Untuk menghitung pengeluaran BBM, BBG, BBM non subsidi dan sebagainya dengan menggunakan Persamaan (3) sampai (9) di atas maka pada tahun pertama (2011) untuk menghitung pengeluaran BBM yaitu dengan persamaan $P_{1}=G_{1} * H_{1}$ maka hasil yang di dapat untuk pengeluaran BBM adalah $R p$. 548.415.000.000. Untuk menghitung pengeluaran BBG yaitu dengan persamaan $P_{2}=G_{2} * H_{2}$ maka hasilnya sebesar $R p$. 312.230.940.000. Dengan menggunakan Persamaan (5) yaitu $P_{3}=G_{1} * H_{3}$ maka hasil yang didapat untuk pengeluaran BBM non subsidi sebesar Rp. 792.155.000.000. Dihitung penghematan bahan bakar dengan menggunakan Persamaan (6) yaitu $S_{1}=P_{1}-P_{2}$ maka hasil sebesar $R p$. 236.184.060.000. Dengan menggunakan Persamaan (7) yaitu $S_{2}=P_{3}-P_{2}$ maka hasil yang didapat untuk penghematan subsidi sebesar $R p$. 479.924.060.000. Investasi yang dikeluarkan pada tahun pertama dapat dihitung dengan menggunakan Persamaan (8) yaitu $I=\left(J_{n}-J_{n-1}\right) * H_{4}$ maka besarnya investasi adalah $R p$. 417.840.000.000. Nilai keuntungan yang di dapat menggunakan Persamaan (9) yaitu $B=\left(S_{1}+S_{2}\right)-I$ maka besarnya keuntungan adalah $R p$. 298.268.120.000

Untuk tahun ke-2 sampai ke-5 dapat dihitung dengan menggunakan persamaan yang sama, sehingga total selama 4 tahun untuk pengeluaran BBM sebesar $R p$. 935.577.500.000, pengeluaran BBG sebesar Rp. 2.809.988.790.000, pengeluaran BBM non subsidi sebesar $R p$. 7.129.167.500.000, penghematan biaya bahan bakar sebesar Rp. 2.125.588.710.000, penghematan subsidi sebesar $R p$. 4.319.178.710.000, investasi sebesar $R p$. 835.644.000.000, dan keuntungan yang didapat sebesar $R p$. 5.609.123.420.000.

Jadi selama 5 tahun dengan investasi sebesar 1,2 triliyun rupiah akan mendapatkan keuntungan sebesar 5.9 triliyun rupiah. Keuntungan yang didapat berupa penghematan subsidi dan penghematan bahan bakar. Untuk kabupaten/kota yang lainnya perhitungannya sama seperti Bandung dan selama 5 tahun mendapatkan keuntungan seperti yang tertera pada Tabel 6 di bawah ini. 
Tabel 6.

Perhitungan keuntungan yang diperoleh.

\begin{tabular}{lrrrr}
$\begin{array}{l}\text { Kabupaten } \\
\text { dan Kota }\end{array}$ & $\begin{array}{r}\text { Total Investasi } \\
(\mathbf{R p})\end{array}$ & $\begin{array}{r}\text { Total Penghematan } \\
\text { Bahan Bakar (Rp) }\end{array}$ & $\begin{array}{r}\text { Total Penghematan } \\
\text { Subsidi (Rp) }\end{array}$ & $\begin{array}{r}\text { Total Keuntungan } \\
(\text { Rp) }\end{array}$ \\
\hline Depok & 257.35 .000 .000 & 484.889 .538 .000 & 985.291 .538 .000 & 1.212 .829 .076 .000 \\
\hline Cibinong & 250.764 .000 .000 & 472.496 .997 .000 & 960.109 .997 .000 & 1.181 .842 .994 .000 \\
\hline Bogor & 210.228 .000 .000 & 396.113 .634 .000 & 804.899 .634 .000 & 990.785 .268 .000 \\
\hline Bekasi & 625.908 .000 .000 & 1.179 .305 .946 .000 & 2.396 .339 .946 .000 & 2.949 .737 .892 .000 \\
\hline Cikarang & 291.048 .000 .000 & 548.371 .635 .000 & 1.114 .286 .635 .000 & 1.371 .610 .270 .000 \\
\hline Karawang & 112.440 .000 .000 & 211.846 .656 .000 & 430.470 .656 .000 & 529.877 .312 .000 \\
\hline Purwakarta & 41.580 .000 .000 & 78.323 .301 .000 & 159.152 .301 .000 & 195.895 .602 .000 \\
\hline Cirebon & 119.844 .000 .000 & 225.806 .070 .000 & 458.836 .070 .000 & 564.798 .140 .000 \\
\hline Bandung & 1.253 .484 .000 .000 & 2.361 .772 .770 .000 & 4.799 .102 .770 .000 & 5.907 .391 .540 .000 \\
\hline
\end{tabular}

Selain keuntungan dari segi penghematan subsidi, penghematan bahan bakar dan penghematan biaya operasional, manfaat lain dari konversi dari BBM ke BBG adalah pengurangan emisi. Dari data pada Tabel 3 dapat disimulasikan besarnya pengurangan emisi gas buang kendaraan selama 5 tahun dengan asumsi pengurangan emisi berdasarkan data success story dari Pakistan yaitu pengurangan emisi $\mathrm{CO}_{2}$ $=0,0001 \mathrm{~kg} / \mathrm{km}, \mathrm{CO}=0,00216 \mathrm{~kg} / \mathrm{km}, \mathrm{NOx}=$ $0,00171 \mathrm{~kg} / \mathrm{km}, \quad \mathrm{HC}=0,000252 \mathrm{~kg} / \mathrm{km}$, dan Partikel $=0,002142 \mathrm{~kg} / \mathrm{km}$. Serta asumsi jarak tempuh $100 \mathrm{~km} /$ hari dan jumlah hari dalam 1 tahun adalah 350 hari.

Sebagai contoh, perhitungan emisi pada kabupaten/kota Bandung, dengan menggunakan Persamaan (10) dapat dihitung emisi pada tahun pertama (2011) untuk emisi $\mathrm{CO}_{2}$ yaitu dengan persamaan $\quad \operatorname{Em}\left(\mathrm{CO}_{2}\right)=V_{E m}\left(\mathrm{CO}_{2}\right) * \sum_{i=1}^{5} J_{n} *$ $J_{3} * J_{2}$ maka pengurangan $\mathrm{CO}_{2}$ sebesar 121.870 $\mathrm{kg}$. Sementara untuk emisi $\mathrm{CO}$ yaitu dengan persamaan $E m(C O)=V_{E m(C O)} * \sum_{i=1}^{5} J_{n} * J_{3} *$ $\mathrm{J}_{2}$ maka diperoleh nilai pengurangan emisi $\mathrm{CO}$ sebesar 2.632.392 kg. Untuk emisi NOx menggunakan persamaan $E m(N O x)=$
$V_{E m(N O x)} * \sum_{i=1}^{5} J_{n} * J_{3} * J_{2}$ maka pengurangan emisi NOx sebesar 2.083.977 $\mathrm{kg}$. Perhitungan emisi HC menggunakan persamaan $\operatorname{Em}(H C)=$ $V_{E m(H C)} * \sum_{i=1}^{5} J_{n} * J_{3} * J_{2}$ maka besarnya pengurangan emisi $\mathrm{HC}$ adalah $307.112 \mathrm{~kg}$. Dan untuk emisi partikel dengan persamaan $E m($ partikel $)=V_{\text {Em }(\text { partikel })} * \sum_{i=1}^{5} J_{n} * J_{3} *$ $J_{2}$ maka besarnya pengurangan emisi partikel adalah $2.610 .455 \mathrm{~kg}$.

Dengan menggunakan persamaan yang sama dapat dihitung pengurangan emisi pada tahun ke-2 sampai tahun ke-5. Jadi total pengurangan emisi di Bandung dari tahun 2012 sampai tahun 2015 mempunyai rincian sebagai berikut; untuk emisi $\mathrm{CO}_{2}$ sebesar $1.096 .795 \mathrm{~kg}$, emisi $C O$ sebesar $23.690 .772 \mathrm{~kg}$, emisi $N O x$ sebesar $18.755 .195 \mathrm{~kg}$, emisi $H C$ sebesar $2.763 .923 \mathrm{~kg}$, dan emisi Partikel sebesar $23.493 .349 \mathrm{~kg}$.

Selanjutnya perhitungan pengurangan emisi untuk kabupaten/kota yang lain menggunakan cara yang serupa seperti perhitungan di atas. Total pengurangan emisi selama 5 tahun untuk setiap kabupaten/kota dapat dilihat pada Tabel 7 di bawah ini.

Tabel 7.

Pengurangan emisi (kg) selama 5 tahun.

\begin{tabular}{lrrrrr} 
Kabupaten dan Kota & $\mathbf{C O}_{\mathbf{2}}$ & $\mathbf{C O}$ & NOx & HC & Partikel \\
\hline Depok & 250.201 & 5.404 .342 & 4.278 .437 & 630.507 & 5.359 .305 \\
\hline Cibinong & 243.807 & 5.266 .220 & 4.169 .091 & 614.392 & 5.222 .335 \\
\hline Bogor & 204.393 & 4.414 .889 & 3.495 .120 & 515.070 & 4.378 .098 \\
\hline Bekasi & 608.517 & 13.143 .967 & 10.405 .641 & 1.533 .463 & 13.034 .434 \\
\hline Cikarang & 282.958 & 6.111 .882 & 4.838 .573 & 713.053 & 6.060 .950 \\
\hline Karawang & 109.312 & 2.361 .139 & 1.869 .235 & 275.466 & 2.341 .463 \\
\hline Purwakarta & 40.415 & 872.953 & 691.088 & 101.845 & 865.679 \\
\hline Cirebon & 116.515 & 2.516 .724 & 1.992 .407 & 293.618 & 2.495 .751 \\
\hline Bandung & 1.218 .665 & 26.323 .164 & 20.839 .172 & 3.071 .036 & 26.103 .804 \\
\hline Total & $\mathbf{3 . 0 7 4 . 7 8 3}$ & $\mathbf{6 6 . 4 1 5 . 2 8 0}$ & $\mathbf{5 2 . 5 7 8 . 7 6 4}$ & $\mathbf{7 . 7 4 8 . 4 5 0}$ & $\mathbf{6 5 . 8 6 1 . 8 1 9}$ \\
\hline
\end{tabular}


Dari data pada Tabel 7 dapat dihitung besarnya $C D M$ yang dihasilkan yaitu dengan pengurangan emisi 1 ton $\mathrm{CO}_{2}$ akan menghasilkan $\$ 10$. Perhitungan $C D M$ ini sesuai menggunakan Persamaan (11) di atas. Sebagai contoh kabupaten/kota Bandung, pada tahun pertama (2011) $C D M$ untuk $\mathrm{CO}_{2}$ dengan persamaan $C D M$ $\left(\mathrm{CO}_{2}\right)=\left(\operatorname{Em}\left(\mathrm{CO}_{2}\right) / 1000\right) * \$ 10$ menghasilkan $\$$ 1.219. Untuk CO menggunakan persamaan $C D M(C O)=(\operatorname{Em}(C O) / 1000) * \$ 10$ menghasilkan \$ 1.219 dan untuk HC menggunakan persamaan $C D M \quad(H C)=$ $(E m(H C) / 1000) * \$ 10$ menghasilkan $\$ 3.071$.

Sedangkan perhitungan $C D M$ di Bandung untuk tahun ke-2 sampai tahun ke-5 menggunakan perhitungan yang serupa seperti perhitungan di atas, sehingga total $C D M$ selama 4 tahun yaitu untuk $C D M\left(C_{2}\right)$ sebesar $\$ 10.968$, $C D M(C O)$ sebesar $\$ 236.908$, dan CDM (HC) sebesar \$27.639. Perhitungan CDM di kabupaten/kota lainnya tertera pada Tabel 8 di bawah ini.

Tabel 8 .

Perhitungan $C D M$

\begin{tabular}{lrrrrr}
\hline Kabupaten dan Kota & $\mathbf{2 0 1 1}$ & $\mathbf{2 0 1 2}$ & $\mathbf{2 0 1 3}$ & $\mathbf{2 0 1 4}$ & $\mathbf{2 0 1 5}$ \\
\hline Depok & $\$ 6.285,40$ & $\$ 9.426,78$ & $\$ 12.569,92$ & $\$ 15.713,06$ & $\$ 18.855,32$ \\
\hline Cibinong & $\$ 6.124,51$ & $\$ 9.186,76$ & $\$ 12.249,01$ & $\$ 15.311,27$ & $\$ 18.372,64$ \\
\hline Bogor & $\$ 5.134,53$ & $\$ 7.700,91$ & $\$ 10.269,06$ & $\$ 12.836,32$ & $\$ 15.402,70$ \\
\hline Bekasi & $\$ 15.285,77$ & $\$ 22.929,54$ & $\$ 30.571,54$ & $\$ 38.214,43$ & $\$ 45.858,19$ \\
\hline Cikarang & $\$ 7.108,33$ & $\$ 10.661,18$ & $\$ 14.214,91$ & $\$ 17.770,39$ & $\$ 21.324,12$ \\
\hline Karawang & $\$ 2.745,74$ & $\$ 4.118,17$ & $\$ 5.491,48$ & $\$ 6.865,67$ & $\$ 8.238,10$ \\
\hline Purwakarta & $\$ 1.015,48$ & $\$ 1.522,77$ & $\$ 2.030,07$ & $\$ 2.537,37$ & $\$ 3.046,43$ \\
\hline Cirebon & $\$ 2.926 .86$ & $\$ 4.390,72$ & $\$ 5.853,71$ & $\$ 7.316,70$ & $\$ 8.780,57$ \\
\hline Bandung & $\$ 30.613,74$ & $\$ 45.919,74$ & $\$ 61.224,85$ & $\$ 76.531,72$ & $\$ 91.838,59$ \\
\hline Total & $\mathbf{\$ 7 7 . 2 4 0 , 3 6}$ & $\mathbf{\$ 1 1 5 . 8 5 6 , 5 7}$ & $\mathbf{\$ 1 5 4 . 4 7 4 , 5 5}$ & $\mathbf{\$ 1 9 3 . 0 9 6 , 9 3}$ & $\mathbf{\$ 2 3 1 . 7 1 6 , 6 6}$ \\
\hline
\end{tabular}

Perhitungan $C D M$ dari Tabel 8 berdasarkan hasil perhitungan $\mathrm{CO}_{2}, \mathrm{CO}$ dan $\mathrm{HC}$ yang dikonversi ke CDM. Total keseluruhan $C D M$ yang dihasilkan selama 5 tahun sebesar US\$ 772.385 .

$C D M$ ini dapat dijual dalam bentuk $C E R$ ke negara-negara dunia ketiga yang mempunyai tingkat polusi udara yang tinggi seperti Pakistan Iran, atau India. Selain itu, CER dapat dijual ke negara-negara industri maju seperti Amerika, Kanada, atau China.

\section{Kesimpulan dan SaRan}

Dari hasil analisa dan perhitungan yang telah dilakukan, dapat diambil beberapa kesimpulan sebagai berikut:

1. Konversi dari BBM ke BBG pada kendaraan mempunyai banyak manfaat. Salah satunya yaitu pengurangan penggunaan BBM yang berarti pengurangan import minyak. Hal ini dapat membantu pemerintah dalam mengurangi subsidi BBM. Selain itu, program konversi ini mengurangi emisi gas buang pada kendaraan bermotor.

2. Kabupaten/kota di Propinsi Jawa Barat yang paling berpotensi berdasarkan banyaknya jumlah kendaraan dan telah adanya jaringan pipa gas adalah Depok, Cibinong, Bogor, dan Bekasi. Sementara Bandung sangat berpotensi karena banyaknya jumlah kendaraan meskipun belum ada jaringan pipa gasnya.

3. Jumlah kendaraan roda 4 di kabupaten/kota yang berpotensi tersebut sebanyak 878.505 unit dan pada tahun pertama kendaraan tersebut dikonversi ke BBG sebanyak 10\% dan kenaikan setiap tahunnya sebesar 5\%. Total kendaraan yang dikonversi selama lima tahun sebanyak 263.554 unit.

4. Dengan banyaknya populasi kendaraan yang dikonversi tersebut, maka SPBG yang harus disediakan selama 5 tahun adalah sebanyak 351 SPBG. Total tersebut didapat berdasarkan perhitungan 1 SPBG yang dapat melayani 750 kendaraan.

5. Dengan investasi sebesar 3,16 triliyun rupiah dapat diperoleh keuntungan sebesar 14,9 triliun rupiah yang berupa penghematan subsidi dan penghematan bahan bakar.

6. Melalui pengurangan emisi $\mathrm{CO}_{2}, \mathrm{CO}$ dan $\mathrm{HC}$ selama 5 tahun sebesar $3.074,8$ ton akan menghasilkan Clean Development Mechanism (CDM) sebesar US\$772.385.

7. Bila program konversi ini berjalan sesuai rencana maka industri peralatan konversi di dalam negeri juga akan berkembang pesat, dan secara otomatis jumlah lapangan kerja juga akan meningkat pula. 
Daftar Pustaka

[1] Kantor Menko Perekonomian, "Kajian Pembiayaan Investasi Transportasi Perkotaan dengan Skema Debt-For-Nature Swap", 2004.

[2] Subdit Pemantauan Pencemaran. (2009). Uji b dalam Darah Anak-anak Sekolah Dasar di Bandung pada Tahun 2008. [Online]. Available: http://www.bplhdjabar.go.id/index.php/bid ang-pengendalian/subid-pemantauanpencemaran/247-uji-pb-dalam-darah-anakanak-sekolah-dasar-di-bandung-padatahun-2008, diakses 8 Juli 2010.

[3] Norris, J. et al, "Light Goods Vehicle CO2 Emission Study: Task Report For Task 5 - Assesment of The Potential For $\mathrm{CO} 2$ Emissions Reduction", The Department for Transport Harwell Didcot. 2009.
[4] Standar Nasional Indonesia. (2009) Peralatan Konversi Bahan Bakar Gas Bumi Bertekanan (Compressed Natural Gas/CNG) Pada Kendaraan Bermotor. [Online]. Available: http://websisni.bsn.go.id/index.php/sni_ma in/sni/cari_simple/18/, diakses 17 Maret 2010.

[5] Australian New Zealand Standard, "Natural Gas (NG) Fuel System for Vehicle Engines", Fifth Edition ed. Sydney: Standard Australia and Standard New Zealand, 2009.

[6] International Standard. (2008, February) NGV Shop Forums. [Online]. Available: http:/NGVshop.com/board/index.php?boa $\mathrm{rd}=6.0$, diakses 19 Maret 2010 .

[7] Kementrian ESDM, BPmigas. [Online]. Available: www.bpmigas.com, diakses 20 Agustus 2010. 